\title{
The Geo-economic Effects of the Expansion of the Panama Canal
}

\section{on World Maritime Trade}

\author{
Massimo Deandreis \\ Italian Economic Research Centre, Naples, Italy
}

\begin{abstract}
This paper originates from a wider research project launched by SRM — an Italian Research Centre related to Intesa Sanpaolo Banking Group and named "Observatory on Maritime Transport and Logistics”. The aim is to contribute to the analysis of the economic impact that strategic maritime infrastructures - like ports and canals - produce on trade and global maritime routes; with a special focus to the effects directed and originating in the Mediterranean. This paper - focused on the New Panama Canal — also offers a perspective view of the new scenarios connected to the fact that thisinfrastructure-opened last June - can accommodate larger ships and new types of vessels including those transporting LNG and LPG (liquefied natural gas and petroleum gas). The expansion of the Canal will help broaden the strategic dimension of Panama allowing it to become a more important maritime hub, especially for the American Continent and the US. To complete the analysis it has been provided a comparison with the Suez Canal on some world routes involving the Americas, the Mediterranean and the Middle East, since these two canals are proposing a massive competition inthe quality of logistics andalso in the pricing policy for the transit fee.
\end{abstract}

Keywords: Panama Canal, Suez Canal, Maritime Transport, Mediterranean, maritime hub, logistics, transit fee, port

\section{The Panama Canal Before the Expansion and the Three Main Effect of the Enlargement}

The Panama Canal has had a significant impact on busting maritime world trade growth, all along the century of its history, since the beginning in 1914. Recent data (Panama Canal Authority statistics and Oscar Bazán, Vice President Panama Canal Authority, 2015) shows that a yearly average of 230 million tonnes ${ }^{1}$ of goods passed through the Canal, on 144 naval routes, involving 1,700 ports and 160 countries. In 2015 around $3 \%-4 \%$ of the world trade volume has passed through Panama.

The annual traffic numbered almost 14,000 ships and the delivered goods were about 230 million tons, 138 million (60\%) of which were bound for the Atlantic-Pacific direction while 92 million (40\%) for the Pacific-Atlantic direction.

In the Atlantic-Pacific direction, the role of Far East countries was major while, in the opposite direction, traffic was mainly bound for the East Coast of the US and towards Europe. Between 2001 and 2015, the traffic

\footnotetext{
Massimo Deandreis, Contract Professor, Department of Management, Turin University; General Director of SRM, Italian Economic Research Centre related with Intesa Sanpaolo Banking Group and President of the Council of Italian Business Economists.

1 Long tons.
} 
bound for Asia grew by $+2.4 \%$ while that of the East Coast of the US grew by $+17 \%$. The countries which mostly used the Canal were the United States, China, Chile, Japan and Peru. Amongst the first 20 users also rank European Countries: Spain (13th), Netherlands (14th), United Kingdom (17th), Belgium (19th) and Italy (20th).

The four busiest routes were: East Coast of the United States-Asia, with 35.8\% of the total transit of goods; US East Coast-West Coast of South America with 16\%; US East Coast-West Coast of Central America with Seven percent and the route Europe-West Coast of South America with 5.9\%².

The Panama Canal is a great generator of economic benefits for the little Latin American Country with \$2.7 billion of revenues and $\$ 1.25$ of managing costs annually and a direct contribution to the Panama GDP of six percent, which becomes $25 \%$ adding the indirect contribution. Relevant is also the economic role of the Colon Free Zone — near the Canal—which counts about 2,600 companies. Its trade amounts to \$21.6 billion, more than $50 \%$ of which are export. The Free Zone imports are mainly from China ( $\$ 3.5$ billion), followed by Singapore ( $\$ 1.9$ billion) and the United States ( $\$ 922$ million). It is expected that the Free-Zone will be enhanced with the expansion of the Panama Canal.

The New Canal, which adds to the previous one, has provided for the realization of two locks, one the Atlantic Ocean and the other on the Pacific. Each is composed of three chambers 55 meters large, 427 meters long and 18.3 meters deep. They are equipped with horizontally sliding sluice systems which can overcome the existing difference in level between the Oceans and Lake Gatun.

The realization of the project, started in 2007, was assigned to an international consortium Grupo Unidos por el Canal which includes the Italian Salini Impregilo SpA (consortium leader), the Spanish company Sacyr Vallhermoso SA, the Belgian Jan de Nul and the Panamanian CUSA and the New Canal was inaugurated last June 26th.

A key element is that the new Canal allows the passage of larger vessels. The new locks will allow the passage of container ships up to 13.000/14.000 TEUs while the limit of the pre-existing Canal was of 4.500-5000 TEUs (Panama Canal Authority statistics and Oscar Bazán, Vice President Panama Canal Authority, 2015). Furthermore, a new type of vessel will also be able to pass, the Liquefied Natural Gas (LNG) and Liquefied Petroleum Gas (LPG), so a new market segment will expand the offer of Panama. More important, the number of transits in the medium to long term will increase. The passage will potentially allow the simultaneous transit of three ships: two of smaller size in the old locks, and one through the new ones; potentially, the passage of further 12 daily vessels will be possible, adding to the pre-existing 38 for a potential total maximum of 50 transits per day. For that reasons the expectation of the rise up to four billion dollar of the annual revenues is quite probable.

\section{Main Evidences on the Impact of the New Panama Canal on Global Routes and Ports}

The expansion of the Canal will help broaden the strategic dimension of Panama allowing it to become an international maritime hub, especially for the American Continent and the US where, according to recent analysis, positive impacts are expected in the main ports of the East Coast of the US. Between 2009 and 2014 the US Federal Government allocated $\$ 320$ million for infrastructure projects along the East and Gulf Coasts where a number of expansion projects of US ports are under way or just concluded. It is the case of the ports of New York

\footnotetext{
${ }^{2}$ Panama Canal Authority.
} 
and New Jersey that have completed the dredging operations for the accommodation of larger vessels, as well as the ports of Savannah and Charleston. These investments will allow intercepting the new ships Post-Panamaxpassing through the Canal and to bust traffic to the US East Coast ports (Rodrigue \& Notteboom, 2015).

But the New Canal is also expected to have impact in a more broaden and global dimension because the Panama main competitor is on the other side of the globe: the Suez Canal, in Egypt, that has also been recently enlarged (SRM in cooperation with ALEXBANK, 2015). A clear example of competition is represented by the Far East-US East Coast route which is one of the most travelled in the world (7.4 million TEUs per year). If in 2010, 15 vessels passed weekly via Panama and four via Suez; the figure in July 2016 was - for the same route-13 ships travelling via Panama and eight via Suez. The re-balance process in favour of Suez was still clear before the enlargement of both Canals. A tendency that is expected to reinforce in the following years (Alphaliner, 2016).

On the basis of a simulation carried out in a SRM recent study (SRM, 2015) on ships of 12,000 TEUs which will be able to pass through the new Canal, in terms of time and costs, Panama remains competitive (but with light advantage) on some strategic routes. Panama competes with Suez both on the Shanghai-New York route where estimations say that the cost to transit per TEU is $\$ 820$ (to and fro), against the $\$ 830$ of Suez, both on the route Hong Kong-New York where the cost of the trip per TEU is $\$ 830$ against the $\$ 855$ of Suez. On the routes Shanghai-Rotterdam and Yokohama (JAP)-Rotterdam, instead, the transit through Suez remains more competitive.

However, a discount-fee measure of the Suez Canal Authority of very recent approval could have negative effects for Panama. Last June 6th, 2016 Suez launched a tariff line that provides a discount of up to 65\% on some container routes coming from the American ports on the East Coast and bound toward the ports of South and South East $\mathrm{Asia}^{3}$. This decision may be a strong incentive to intensify the passages through Suez, to increase the competitiveness against Panama (which will probably be urged to review its tariff's strategies) and discourage the routes that circumnavigate the Cape of Good Hope also as a result of the decrease in the oil price.

Another key issue is the naval gigantism phenomena. Bigger and bigger ships are under construction. One of the biggest container ships currently circulating in the Oceans is the MSC "Zoe" of 19. 224 TEUs for 400 meters long. These kinds of vessels are unable to pass through the New Panama Canal, while there are no limits of ship dimension for the Suez Canal. An issue that could mark - in perspective-a fundamental point in favour of the Suez Canal, especially for routes from Asia to East Coast of the US where Chinese Carriers normally uses megaships.

All these factors will also produce effects in the Mediterranean, contributing to increase its centrality and to strengthen the routes of traffic which coming from the Atlantic enters the Mediterranean and after Suez continue toward the Far East. At the same time, also China is actively working to open a maritime "Silk Road" of immediate interest for its Mediterranean trades; in relation to this strategy there is a strengthening of the routes which from the Far East are directed toward the Mediterranean. These factors also contribute to explain the growing role of the Chinese shipping companies in the Mediterranean, like COSCOS who bought the Port of

\footnotetext{
${ }^{3}$ Circular 2/2016 Suez Canal Authority.
} 
Pireo in Greece and has a significant share of Port Said in the Egyptian Mediterranean Cost, close to the Suez Canal outlet.

So clearly the expansion of the Panama Canal will also have a direct impact on Suez. The New Panama will push the search for more efficient economies of scale in the shipping industries where there are no signs that the naval gigantism phenomena will stop. It is reasonable to think that, for all these reasons, shipping companies will choose to better exploit sea-routes that assure multiple stops, where to unload containers and load others. In this way, shipping companies will assure the highest average load level all along the route for their cargos and a better exploitation of the economies of scale, especially for megaships. South and North American routes through Panama (with a lot of ports of emerging and leading economies) and Asia-East Cost of America via Suez (passing through South European ports, the Gulf area, India and Far East) better ensure these conditions rather than the routes from Asia to East Coast of America sailing solitary long days in the Pacific before joining the Panama Canal. Thus, we understand the potential re-balance shift in favor of Suez and Mediterranean for the routes to and from Asia, while Panama will grow reinforcing his Pan American hub role, still remaining competitive with Suez for ships under 12.000 TEUs dimension.

\section{Conclusions}

The expansion of the Panama Canal is a primary importance engineering work - due in large part to an Italian company - which will have an impact in the short and in the long term on the routes and on global port facilities. Main statistic evidences and analysis, outlines a scenario in which the new Panama Canal, while remaining a hub of global importance, reinforces its role, above all, as a great regional American Canal which will have the effect of strengthening the ports on the Atlantic coast of the United States. This will also have an impact on the Mediterranean; strengthening the centrality of the routes which originate in Asia and head toward the East Coast of the United States passing through the Suez Canal which still remain the main competitor of Panama. Then, there is a direct impact expected on the Mediterranean where is estimated an average yearly increase of $2.2 \%$ in the volume of goods traded, as a direct consequence of the new Panama Canal.

\section{References}

Alphaliner. (2016). Weekly Newsletter, No. 28.

Panama Canal Authority. (various years). Annual Report

Panama Canal Authority statistics and Oscar Bazán, Vice President Panama Canal Authority. (2015). Panama Canal Expansion: Implications and Opportunities. Trade Links with the New Latin America, Panama, 25th June 2015.

Rodrigue, J. P., \& Notteboom, T. (2015). The legacy and future of the Panama Canal. TR News, No. 296, January-February. SRM. (2015) The economic effects of the expansion of the Panama Canal on maritime trade. Retrieved from http://www.sr-m.it SRM in cooperation with ALEXBANK. (2015). The new Suez Canal: Economic impact on Mediterranean maritime trade. Retrieved from http://www.sr-m.it

SRM. (2016). Italian maritime economy, 3rd Annual Report

UNCTAD. (2015). Review of maritime transport, United Nations Publication.

US Department of Transportation, Maritime Administration. (2013). Panama Canal expansion study. Phase 1 Report: Development in trade and national and global economies

Van Der Putten, F. P. ( 2014). Chinese investment in the port of Piraeus, Greece: The relevance for the EU and the Netherlands. Clingendael Report, 14th February 2014.

World Bank. (2015). Panama: Locking in success. A systematic country diagnostic. 